\title{
INTEGRATION OF MIXED-CROPPING AND RICE-DUCK CO- CULTURE HAS ADVANTAGE ON ALLEVIATING THE NONPOINT SOURCE POLLUTION FROM RICE (ORYZA SATIVA L.) PRODUCTION
}

\author{
LI, M. J. ${ }^{1}-$ LI, R. H. ${ }^{1,4}-$ ZHANG, J. E. ${ }^{1,2,3,4^{*}}-$ GUO, J. ${ }^{1}$-ZHANG, C. X. ${ }^{1}-$ LIU, S. W. ${ }^{1}-$ HEI, Z. \\ W. ${ }^{1}-$ QIU, S. Q. ${ }^{1}$ \\ ${ }^{I}$ Department of Ecology, College of Natural Resources and Environment, South China \\ Agricultural University, Wushan Road, Tianhe District, Guangzhou 510642, Guangdong \\ province, P.R. China
}

${ }^{2}$ Guangdong Engineering Technology Research Centre of Modern Eco-agriculture and Circular Agriculture, Guangzhou 510642, Guangdong province, P.R. China

\author{
${ }^{3}$ Key Laboratory of Agro-Environment in the Tropics, Ministry of Agriculture, Guangzhou \\ 510642, Guangdong province, P.R. China \\ ${ }^{4}$ Guangdong Province Key Laboratory of Eco-Circular Agriculture, Guangzhou 510642, \\ Guangdong province, P.R. China \\ ${ }^{*}$ Corresponding author \\ e-mail: jeanzh@scau.edu.cn; phone: +86-020-8528-0211; fax: +86-020-8528-1885
}

(Received 25 ${ }^{\text {th }}$ Aug 2019; accepted 25 ${ }^{\text {th }}$ Nov 2019)

\begin{abstract}
With the rapid development of agricultural industrialization, agricultural nonpoint source pollution, which occurs when synthetic chemical additives (e.g. fertilizer, pesticides, and herbicides) runoff into rivers or lakes, has become a major concern. To explore the approaches of reducing the application of chemical additives, we conducted a field experiment to test whether the integrated farming systems would alleviate the nonpoint source pollution. Specifically, we tested whether mixed-cropping or mixed-cropping plus duck co-culture (MCDC) systems with optimized rice (Oryza sativa L.) cultivars could reduce nutrients runoff or leaching from paddy field. We found that compared to the monocropping systems, the electrical conductance (EC), oxidation-reduction potential (ORP), the contents of dissolved oxygen (DO), nitrates $\left(\mathrm{NO}_{3}{ }^{-}\right)$, ammonium $\left(\mathrm{NH}_{4}{ }^{+}\right)$, total nitrogen (TN), total phosphorus (TP) and total potassium (TK) of paddy water in MCDC systems all increased during the rice-growing stages. The contents of the TN, TP, and TK of paddy water in MCDC systems were $45.35 \%, 52.43 \%$ and $40.47 \%$ higher than those in the mono-cropping systems, respectively. Compared to the conventional monocropping, the mixed-cropping systems could alleviate nonpoint source pollution by decreasing the application of synthetic chemicals to rice paddies, the rice-duck co-culture system had significantly lower additions of agro-chemicals to paddy fields, which decreased the loss/runoff/leaching rates of nitrogen, phosphorus and potassium from paddy fields into the surrounding water areas by $32.73 \%, 8.72 \%$ and $31.88 \%$, respectively. Considering that the MCDC systems exerted similar/even better performances as/than the rice-duck co-culture system and the rice mixed-cropping system, we deduced that the MCDC systems could also could alleviate nonpoint source pollution to a certain extent.
\end{abstract}

Keywords: mixed-cropping, rice-duck co-culture, rice cultivars, nutrient runoff, paddy water, nonpoint source pollution

\section{Introduction}

Nonpoint source pollution is a serious problem that degrades surface waters and aquatic ecosystems (Dodds et al., 2008). Nutrients, sediment, and other pollutants from human-altered landscapes can damage the integrity of freshwater systems (Hunsaker et 
al., 1995). Technologies and techniques to prevent and control industrial point source pollution are becoming more mature and widely implemented, but agricultural nonpoint source pollution has become the main cause of eutrophication in the world's aquatic environments (Ma et al., 2012). Water pollution has become an increasingly serious problem in China since the 1970s (Jusi, 1989). Literature reviews have highlighted concerns of agricultural nonpoint pollution in China entailing excessive inputs of fertilizers, pesticides, herbicides, and heavy metals into waters and soils (Smil, 1997; Schwarzenbach et al., 2010; Sun et al., 2012; Kale, 2013; Moldes et al., 2013).

At present, China is the largest rice growing and consuming country in the world (Thomas et al., 2011). In 2017, China accounted for 15.7\% of the world's rice planting area and $28.8 \%$ of the world's total rice output. However, the area of cultivated land available for rice cultivation in China is gradually decreasing, while the population and demand for food are increasing (Cheng et al., 2007; Chen et al., 2019; Yin et al., 2019). Studies have shown that the farmers in the country currently use chemical fertilizers at very high rates (Wu, 2011; Yin et al., 2018; Wang et al., 2019). For instance, Li et al. (2019a) reported that the average rates of nitrogen $(\mathrm{N})$, phosphorus $(\mathrm{P})$ and potassium $(\mathrm{K})$ fertilizers runoffs in orchards of major citrus producing regions of China were as high as $485 \mathrm{~kg} \mathrm{ha}^{-1}(\mathrm{~N}), 198 \mathrm{~kg} \mathrm{ha}^{-1}\left(\mathrm{P}_{2} \mathrm{O}_{5}\right)$, and $254 \mathrm{~kg} \mathrm{ha}^{-1}\left(\mathrm{~K}_{2} \mathrm{O}\right)$, respectively. Sun et al. (2019) found that more than $85 \%$ of sampled farming households used complex fertilizers in rice production, and that complex fertilizers account for more than half of the total use of chemical fertilizers. These overuse of chemical fertilizers could damage streams and rivers (Liu et al., 2018; Qiu, 2018; Reddy et al., 2018), pollute groundwater (Cui et al., 2018), and lead to declines in biodiversity (Asai et al., 2011; Sun et al., 2015). Nonpoint source pollution from rice farms is becoming particularly bad in southern China, a region with relatively high precipitation.

To reduce nonpoint source pollution and improve water quality, it is important to adopt techniques that reduce the use of synthetic chemical additives, such as chemical fertilizers, pesticides and herbicides (Saraswat et al., 2016). Ecological agriculture technologies, including livestock farming, intercropping and mixed farming, show promise for improving water quality and increasing biodiversity in rice paddy fields (Wu et al., 2013; Li et al., 2019b). Teng et al. (2019) found that rice-duck integrated organic farming protected water quality in Dianshan Lake and raised the incomes of local farmers. Another study found that hedgerow intercropping could fix nitrogen, reducing the need for chemical fertilizers, hedgerows also, prevented soil erosion, took up soil nutrients, and filtered pollutants (Zhang et al., 2008).

Rice-duck co-culture, in particular, is an integrated farming technology that helps control rice pests and weeds, and improve rice production, grain quality, and ecological sustainability (Zhang et al., 2008; Luo, 2018; Yang et al., 2018; Li et al., 2019c). Also, there is a mixed-cropping system, which cultivates multiple crop species or cultivars simultaneously in the same field for a significant part of their life cycles, using the space more efficiently and spreading risks more uniformly (Vandermeer et al., 1998; Lithourgidis et al., 2011). Numerous studies have reported that intensive integrated cropping systems, like rice-duck co-culture, have advantages over mono-cropping systems, largely due to reductions in pest incidence (Gold, 1993; Pridham et al., 2007) and more efficient use of nutrients, water, and solar radiation (Mason et al., 1988).

However, the relative effectiveness of different integrated cropping approaches for reducing nutrients loss, runoff, or leaching is still unknown. In this study, we compared the effects of rice mono-cropping system, mixed-cropping system with different rice 
cultivars, and mixed-cropping of different rice cultivars plus duck co-culture (MCDC) on paddy water nutrients in paddy fields in southern China. We hypothesized that mixedcropping system and mixed-cropping plus duck co-culture system with optimized rice cultivars would have more ecological benefits to improve the absorption of nutrients by rice plants and reduce nutrients loss, runoff, and leaching from the paddy fields.

\section{Material and methods}

\section{Site description}

We conducted our field experiment at Zengcheng Teaching and Research Farm $\left(23^{\circ} 14^{\prime} \mathrm{N}, 113^{\circ} 38^{\prime} \mathrm{E}\right)$, South China Agricultural University, Guangzhou, China in 2018, where subtropical monsoonal climate was characterized by warm winter and hot summer, with an annual rainfall of $1,738 \mathrm{~mm}$ and an average temperature of $22.75^{\circ} \mathrm{C}$ (Fig. I). The soil in the experimental site was sandy loam. The nutrients of the soil were determined at epipedon prior to the experiment. The soil contained organic matter of $15.62 \mathrm{~g} \cdot \mathrm{kg}^{-1}$, total nitrogen of $0.81 \mathrm{~g} \cdot \mathrm{kg}^{-1}$, total phosphorous of $0.55 \mathrm{~g} \cdot \mathrm{kg}^{-1}$, total potassium of $12.84 \mathrm{~g} \cdot \mathrm{kg}^{-1}$, available nitrogen of $61.62 \mathrm{mg} \cdot \mathrm{kg}^{-1}$, available phosphorus of $39.11 \mathrm{mg} \cdot \mathrm{kg}^{-1}$, and available potassium of $69.19 \mathrm{mg} \cdot \mathrm{kg}^{-1}$. The soil had a $\mathrm{pH}$ value of 4.88 .

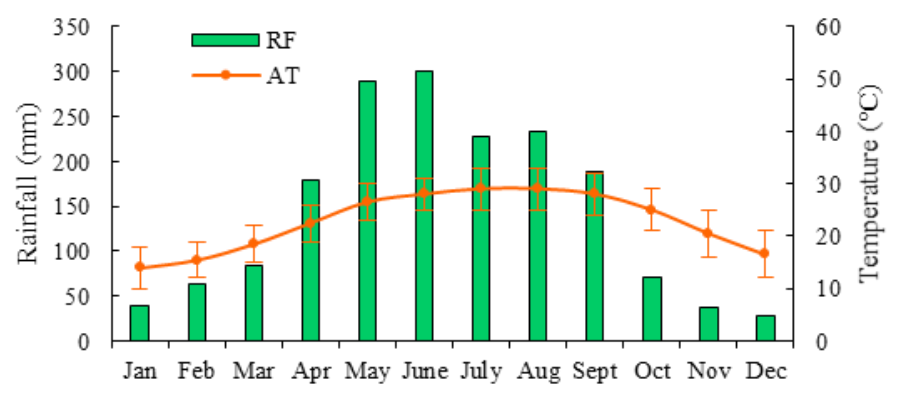

Figure 1. Monthly rainfall (RF) and average temperature (AT) during 2018, the year of the experiment, in Zengcheng, Guangzhou, Guangdong, China.Temperature errorbars indicate the highest and lowest recorded temperatures.

\section{Experimental design and treatment}

The experiment used completely random design with thirteen treatments and three replicates for each treatment (see Appendix Fig. S1). Each plot covered an area of $35 \mathrm{~m}^{2}$ $(5.0 \mathrm{~m} \times 7.0 \mathrm{~m})$. In this study, we used five traditional indica rice cultivars, including four from Rice Research Institute of Guangdong Academy of Agricultural Sciences (Yuenongsimiao, Meixiangzhan 2, Huangguangyouzhan, and Huanghuazhan) and one from National Engineering Research Centre of Plant Breeding at South China Agricultural University (Huahang 31) (Table S1), here labelled as A, B, C, D, and E, respectively. We selected four combinations of cultivars (BC, ACD, BDE, and ABDE) according to their growth period, plant height, grain yield and quality, and resistance to diseases of the five rice cultivars (Table S1), and also according to the screening of combinations optimized by pot experiments (Li et al., 2019b). Seeds were mixed for all combinations with the rice cultivars at equal weight ratios. Each mixed-cropping combination had six plots, three with and three without co-culture of ducks. The five 
rice cultivars were also mono-cropped in pure plots as the corresponding controls of the three replicates, but without duck co-culture.

\section{Agronomic management}

All seeds were soaked in water for $48 \mathrm{~h}$ at room temperature and germinated under suitable conditions. Germinated seeds of each combination were sown on 15th March 2018 in the fields of Zengcheng Teaching and Research Farm. Seedlings of all combinations were transplanted to the field plots on 21th April 2018 at the normal spacing of $20 \mathrm{~cm} \times 20 \mathrm{~cm}$. In each plot, we applied organic fertilizer $\left(6,750 \mathrm{~kg} \cdot \mathrm{ha}^{-1}\right.$, among which $\mathrm{N} \geq 1.63 \%, \mathrm{P}_{2} \mathrm{O}_{5} \geq 3.53 \%, \mathrm{~K}_{2} \mathrm{O} \geq 1.92 \%$ and organic matter $\geq 46 \%$ ) by broadcasting before rice transplanting.

Seven days after transplanting rice seedlings, we released ducklings into the specified plots at a density of 3 ducks per plot, based on the recommended population of Zhang et al. (2005). Each paddy field plot was surrounded by $50 \mathrm{~cm}$ high nylon mesh fencing to prevent ducks from escaping. The ducks were kept in the fields until rice reached its heading stage on 18th June in 2018. Water was kept at 6-8 cm deep while ducks were in the fields, but irrigation was stopped one week before the rice harvest. Photos of different growth periods in the paddy field of this study were shown in Fig. 2.

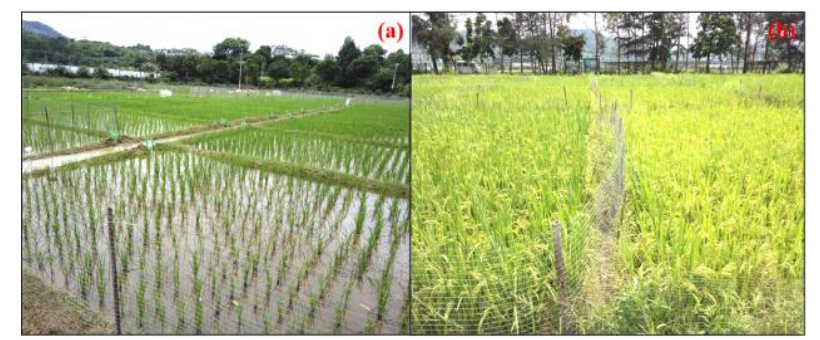

Figure 2. Photos of different growth periods in the paddy field of this study. (a): Returning green stage; (b): Full heading stage

\section{Trait measurements}

Physical and chemical parameters of paddy water, such as $\mathrm{pH}$ value, temperature (Temp), electrical conductivity (EC), oxidation-reduction potential (ORP), and dissolved oxygen content (DO), were analyzed using $\mathrm{pH}$ meter, EC meter, ORP meter (KEDIDA, Shenzhen, China), and DO meter (LEICI JPB-607A, Shanghai, China). Measurements were made at 10:00h-11:30h with three repetitions in each plot. Water samples were randomly collected as composites of 5 sub-samples from the surface water $(0-5 \mathrm{~cm})$ within a 2-m-diameter circular area centered in each plot on 5th April (one week before rice seedlings were transplanted), 27th May, 22nd June, and 18th July in 2018 correspondingly. The impurities of all water samples were filtrated with filter papers $(\mathrm{d} 12.5 \mathrm{~cm})$. We measured nitrates $\left(\mathrm{NO}_{3}{ }^{-}\right)$, ammonium $\left(\mathrm{NH}_{4}{ }^{+}\right)$, total nitrogen (TN), total phosphorus (TP) and total potassium (TK).

\section{Data analyses}

All data were expressed as means \pm standard errors. To compare the effects of rice mono-cropping, mixed-cropping with different rice cultivars, and mixed-cropping of different rice cultivars with duck co-cultureon paddy water physical and chemical 
properties, we compared the experimental treatments using one-way ANOVA followed by Fisher's least significant difference post-hoc tests. For example, the data from B and $\mathrm{C}$ mono-cropping systems were pooled, and then compared with the results from $\mathrm{BC}$ mixed-cropping and BC mixed-cropping with duck co-culture. All statistical analyses were performed with R 3.20 (R Development Core Team 2015).

\section{Results}

\section{Environmental background before ducklings released in paddy fields}

Prior to releasing ducklings, the treatment plots did not differ significantly in water physical and chemical characteristics $(\mathrm{pH}$, water temperature, electrical conductance, oxidation-reduction potential, and dissolved oxygen content) (Fig. 3), and also in the contents of nutrients (nitrate, ammonium, total nitrogen, total phosphorus, and total potassium) of paddy water (Fig. 4). These included plots for mono-cropping, mixedcropping and MCDC systems for all combinations of rice cultivars (BC, ACD, BDE, and $\mathrm{ABDE}$ ).
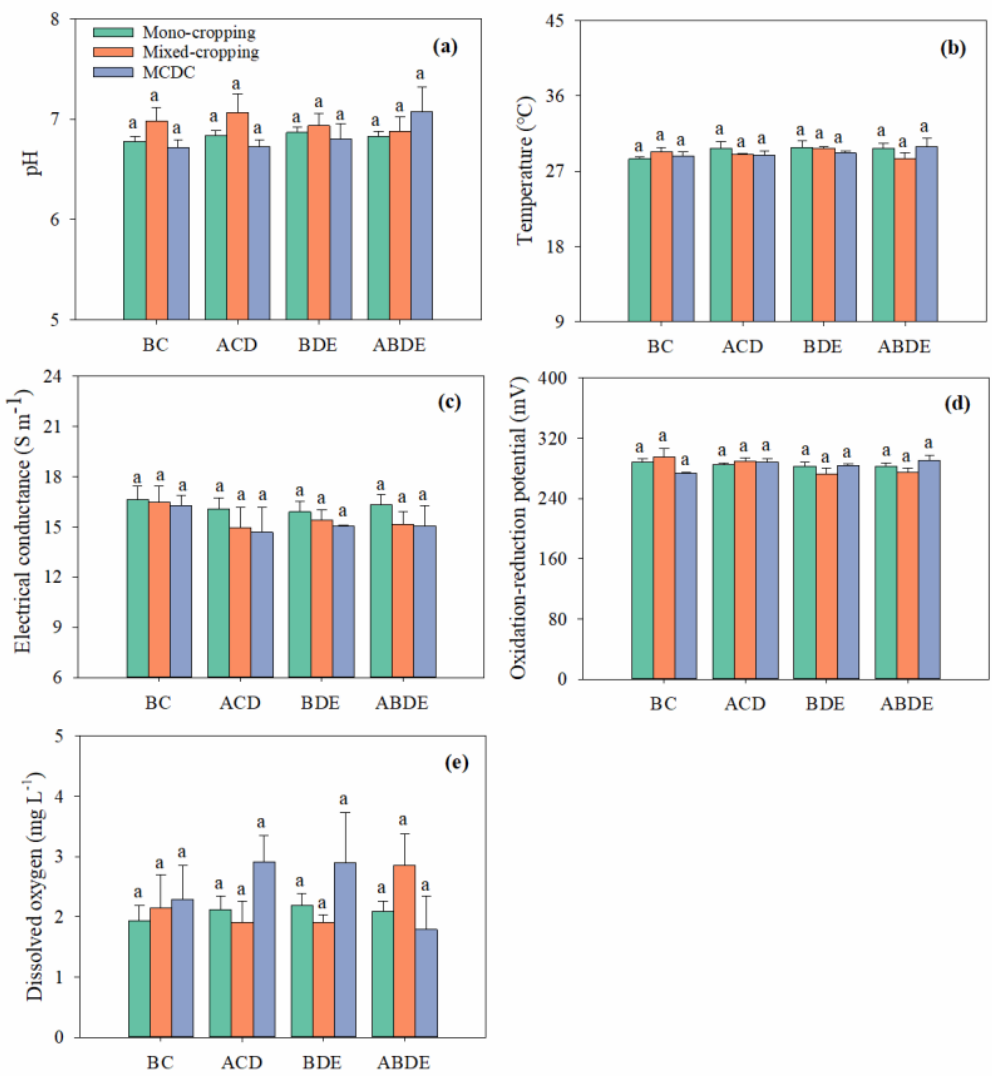

Figure 3. $p H$ value (a), temperature (b), electrical conductance (c), oxidation-reduction potential $(d)$, and dissolved oxygen content (e) of paddy water for mono-cropping, mixedcropping, and MCDC systems before ducklings were released in the paddy fields. MCDC refers to rice mixed-cropping with duck co-culture. Labels on the $x$-axes represent combinations of

rice cultivars, with $A=$ Yuenongsimiao, $B=$ Meixiangzhan 2, $C=$ Huangguangyouzhan, $D=$ Huanghuazhan, E=Huahang 31. The error terms above bars indicates SEs. Different lowercase letters above bars indicate significant differences between the mean values of treatments (Fisher's LSD; P<0.05) 

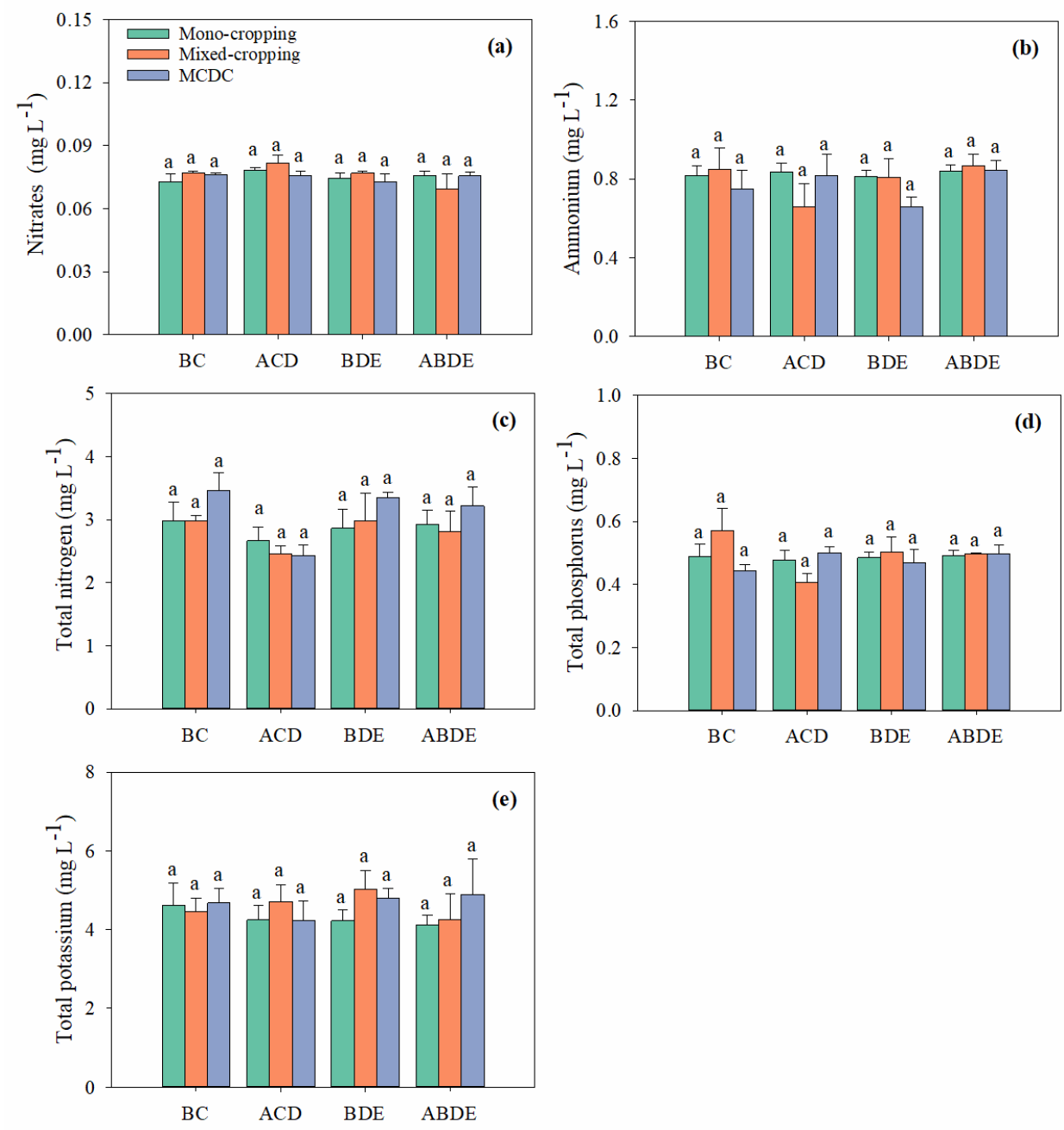

(e)

Figure 4. Concentrations of nitrates (a), ammonium (b), total nitrogen (c), total phosphorus $(d)$, and total potassium (e) of paddy water for mono-cropping, mixed-cropping, and MCDC systems before ducklings were released in the paddy fields. MCDC refers to rice mixed-cropping with duck co-culture. Labels on the $x$-axes represent combinations of rice cultivars, with $A=$ Yuenongsimiao, B=Meixiangzhan 2, C=Huangguangyouzhan, $D=$ Huanghuazhan, $E=$ Huahang 31. The error terms above bars indicates SEs. Different lowercase letters above bars indicate significant differences between the mean values of treatments (Fisher's LSD;

$P<0.05)$

\section{Physical and chemical properties of paddy water}

According to ANOVA analyses, the $\mathrm{pH}$ of MCDC treatments was significantly higher than that of the mono-cropping and mixed-cropping systems on 22nd June and 18th July (Fig. 5). Compared to the mono-cropping and mixed-cropping systems, the MCDC treatments had lower paddy water temperatures on 22nd June and 18th July. The electrical conductance, oxidation-reduction potential, and dissolved oxygen content were all significantly higher in the MCDC systems than in the mono-cropping and mixed-cropping systems on 27th May, 22nd June and 18th July, respectively (Fig. 5). 


$$
-1287-
$$
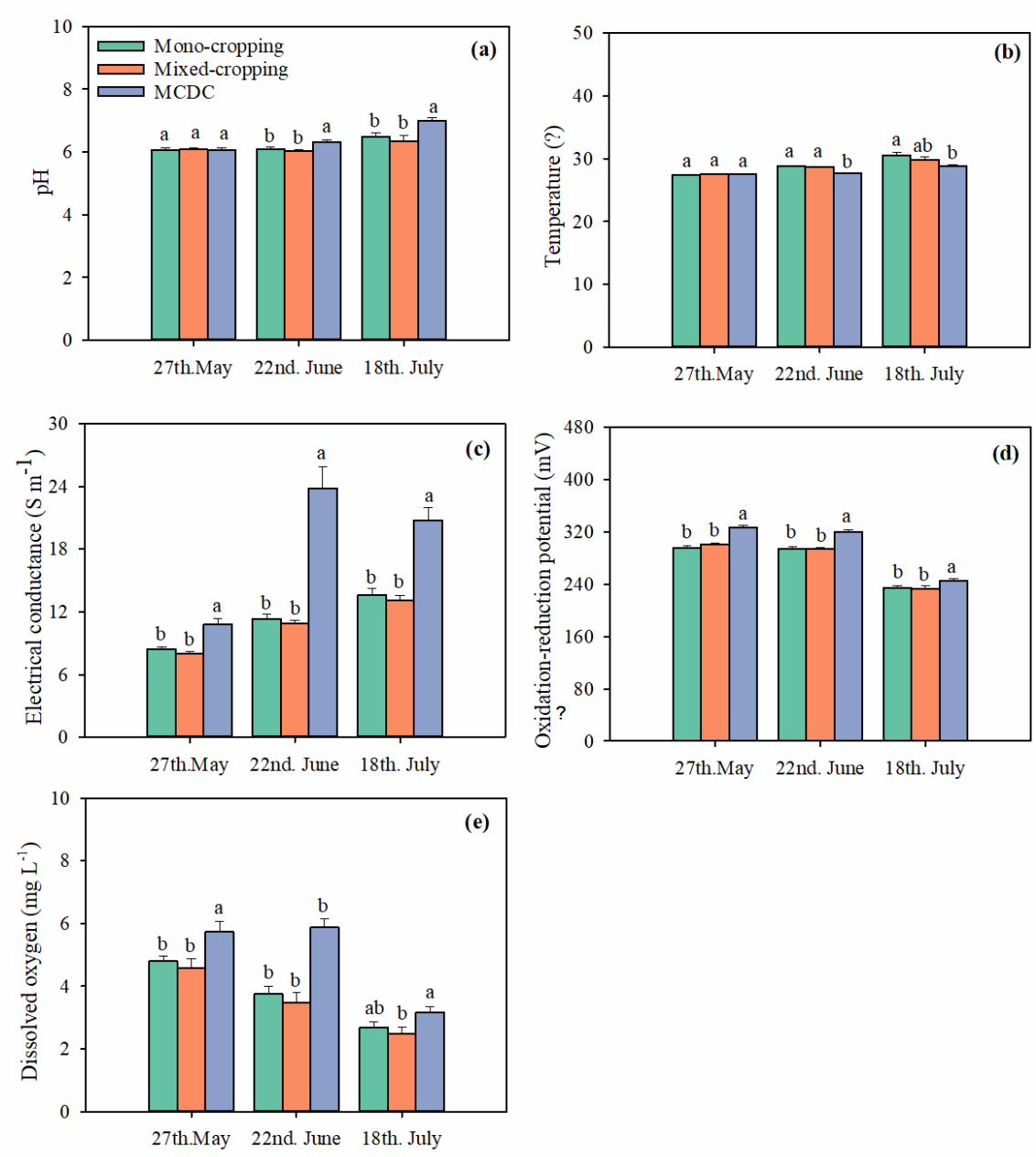

Figure 5. Differences in the water pH value (a), water temperature (b), electrical conductance (c), oxidation-reduction potential (d), and dissolved oxygen (e) for mono-cropping, mixedcropping, and MCDC systems after ducklings were released in the paddy fields in 2018. MCDC refers to rice mixed-cropping plus duck co-culture system. Different letters above bars indicate significant differences between the mean values of treatments (Fisher's LSD; P<0.05)

\section{Nutrient concentration of paddy water}

Compared to the mono-cropping and mixed-cropping systems, the nitrate concentrations of paddy water in MCDC systems were higher at all stages (except 18th July) of rice growth, which exerted an increase status (from 8.67 to $33.39 \%$, and from 6.53 to $27.97 \%$, respectively) (Fig. 6). The ammonium concentration of paddy water in MCDC systems was also significantly higher than that in the other two systems. Similarly, compared to the mono-cropping systems, the concentrations of total nitrogen, total phosphorus, and total potassium of paddy water all improved (39.51-45.35\%, $18.23-52.43 \%$, 34.09-40.47\%) obviously in MCDC systems. Moreover, the concentrations of total nitrogen, total phosphorus, and total potassium of paddy water all significantly increased $(22.96-36.99 \%, 19.14-40.27 \%, 35.03-40.94 \%)$ in the MCDC systems than the mixed-cropping systems. 


$$
-1288-
$$
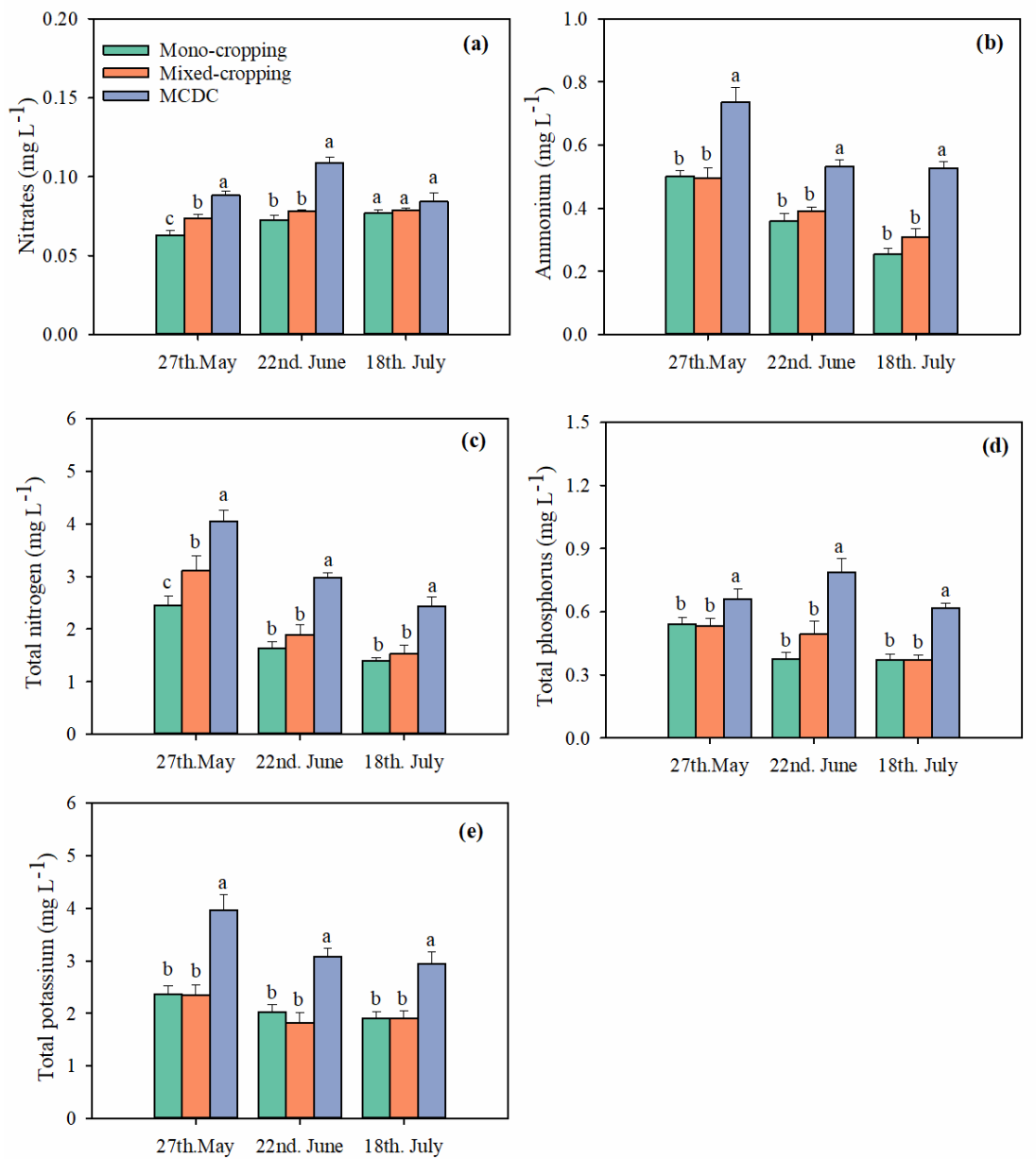

Figure 6. Differences in concentrations of water nitrates (a), water ammonium (b), total nitrogen (c), total phosphorus (d), and total potassium (e) for mono-cropping, mixed-cropping, and MCDC systems after ducklings were released in the paddy fields in 2018. MCDC refers to rice mixed-cropping plus duck co-culture system. Different letters above bars indicate significant differences between the mean values of treatments (Fisher's LSD; $P<0.05$ )

\section{Nutrients loss/runoff/leaching from paddy fields}

Both the mixed-cropping and the rice-duck co-culture required almost no use of chemical fertilizers and pesticides, or other chemical additives (Table 1), but the conventional mono-cropping required much more application of chemical pesticides to protect the rice from being attacked by pests, and required much more compound fertilizers to increase rice production. Compared to the conventional mono-cropping rice system, the rice-duck co-culture systems showed lower rates of nitrogen, phosphorus and potassium loss, runoff, and leaching, which dropped to $32.73 \%, 8.72 \%$, and $31.88 \%$, respectively (Table 1 ). 
Table 1. The rate of the nutrients loss/runofflleakage among the conventional mono-cropping, mixed-cropping system, and rice-duck co-culture

\begin{tabular}{|c|c|c|c|c|c|c|c|c|c|c|c|c|c|}
\hline \multirow[b]{2}{*}{$\begin{array}{l}\text { Farming } \\
\text { systems }\end{array}$} & \multirow[b]{2}{*}{$\begin{array}{c}\mathrm{N} / \mathrm{P} / \\
\mathrm{K}\end{array}$} & \multicolumn{5}{|c|}{ Before rice harvest } & \multicolumn{4}{|c|}{ After rice harvest } & \multirow{2}{*}{\begin{tabular}{|} 
Water nutrients \\
/ (soil nutrients \\
+ rice plant \\
nutrients) \\
$(\%)$
\end{tabular}} & \multirow{2}{*}{\begin{tabular}{|c|} 
Rates of \\
nutrients \\
loss/runoff/l \\
eaching \\
$(\%)$ \\
\end{tabular}} & \multirow[b]{2}{*}{ References } \\
\hline & & $\begin{array}{c}\text { (1) Soil } \\
\text { nutrients of } \\
\text { background } \\
\left(\mathrm{g} \cdot \mathrm{kg}^{-1}\right)\end{array}$ & $\begin{array}{c}\text { (2)Water } \\
\text { nutrients of } \\
\text { background } \\
\left(\mathrm{mg} \mathrm{L}^{-1}\right)\end{array}$ & $\begin{array}{l}\text { Input chemical or } \\
\text { organic fertilizers } \\
\qquad\left(\mathrm{kg} \mathrm{h}^{-1}\right)\end{array}$ & $\begin{array}{l}\text { Input pesticides } \\
\text { /herbicides }\end{array}$ & $\begin{array}{c}\text { Ducks } \\
\text { feces } \\
\text { nutrients } \\
\left(\mathrm{kg} \mathrm{ha}^{-1}\right) \\
\end{array}$ & $\begin{array}{c}\text { (1) Soil } \\
\text { nutrients } \\
\left(\mathrm{kg} \mathrm{ha}^{-1}\right)\end{array}$ & $\begin{array}{l}\text { (2) Water } \\
\text { nutrients } \\
\left(\mathrm{mg} \mathrm{L}^{-1}\right)\end{array}$ & $\begin{array}{l}\text { Plants } \\
\text { nutrients } \\
(\%)\end{array}$ & $\begin{array}{c}\text { Biomass of } \\
\text { rice plant } \\
\left(\mathrm{kg} \mathrm{h}^{-1}\right)\end{array}$ & & & \\
\hline \multirow{3}{*}{$\begin{array}{l}{ }^{3} \text { Conventio } \\
\text {-nal mono- } \\
\text { cropping }\end{array}$} & $\mathrm{N}$ & 62.81 & 0.87 & 231.30 & $1800 \mathrm{~g} \mathrm{~L}^{-1}$ of & - & 65.45 & 1.34 & 1.01 & \multirow{3}{*}{13600} & 0.38 & 39.82 & \multirow{3}{*}{$\begin{array}{l}\text { (Qin et al., } \\
\text { 2010; Quan et } \\
\text { al., 2008; } \\
\text { Wang et al., } \\
\text { 2004; Xiang } \\
\text { et al., 2013) }\end{array}$} \\
\hline & $P$ & 40.54 & 0.07 & 219.15 & $\begin{array}{c}\text { Butachlor } \\
\text { (3 times); } w=50 \%\end{array}$ & - & 38.45 & 0.32 & 0.34 & & 0.23 & 79.42 & \\
\hline & K & 68.97 & 2.45 & 226.00 & $\begin{array}{l}\text { WP; } 250 \mathrm{~g} \mathrm{~L}^{-1} \text { of } \\
\text { Bisultap }\end{array}$ & - & 42.53 & 3.17 & 1.08 & & 0.92 & 41.93 & \\
\hline \multirow{3}{*}{$\begin{array}{l}\text { (3) Mixed- } \\
\text { cropping } \\
\text { system }\end{array}$} & $\mathrm{N}$ & 63.98 & 3.37 & 110.03 & \multirow{3}{*}{ No or less } & - & 65.47 & 1.54 & 1.02 & \multirow{3}{*}{9290} & 0.57 & 13.89 & \multirow{3}{*}{$\begin{array}{l}\text { (Qin et al., } \\
\text { 2010; Wang } \\
\text { et al., 2004) }\end{array}$} \\
\hline & $P$ & 39.75 & 0.74 & 104.03 & & - & 38.93 & 0.37 & 0.35 & & 0.33 & 69.40 & \\
\hline & K & 69.06 & 4.61 & 107.54 & & - & 42.63 & 1.91 & 1.08 & & 0.76 & 22.84 & \\
\hline \multirow{3}{*}{$\begin{array}{l}{ }^{3} \text { Rice-duck } \\
\text { co-culture }\end{array}$} & $\mathrm{N}$ & 61.29 & 3.74 & 110.03 & \multirow{3}{*}{ No } & 14.1 & 68.06 & 2.44 & 1.08 & \multirow{3}{*}{10490} & 0.81 & 7.09 & \multirow{3}{*}{$\begin{array}{l}\text { (Qin et al., } \\
\text { 2010; Wang } \\
\text { et al., 2004) }\end{array}$} \\
\hline & $\mathrm{P}$ & 41.39 & 0.72 & 104.03 & & 21.0 & 43.56 & 0.62 & 0.48 & & 0.42 & 70.70 & \\
\hline & K & 69.60 & 4.65 & 107.54 & & 9.0 & 45.76 & 2.94 & 1.14 & & 1.02 & 10.05 & \\
\hline
\end{tabular}

Rates of nutrients loss/runoff/leaching $(\%)=($ The total amount of N/P/K before rice harvest - The total amount of N/P/K after rice harvest $) \div($ The total amount of $\mathrm{N} / \mathrm{P} / \mathrm{K}$ before rice harvest $) \times 100 \%$;

(1) Soil bulk density of the conventional mono-cropping, mixed-cropping system, and rice-duck co-culture were $1.21 \mathrm{~g} \mathrm{~cm}^{-1}, 1.21 \mathrm{~g} \mathrm{~cm}^{-1}$, and $1.09 \mathrm{~g} \mathrm{~cm}^{-1}$, respectively;

(2) Paddy water density of the conventional mono-cropping, mixed-cropping system, and rice-duck co-culture were considered the same.

${ }^{3}$ The data of the conventional mono-cropping was taken taken from the references, and the data of the mixed-cropping system and rice-duck co-culture were measured in this study (except for the indexes of nutrients from duck feces and plants) 


\section{Discussion}

Few studies evaluated the effect of the mixed-cropping or mixed-cropping plus duck co-culture systems (MCDC) on nutrient leaching or runoff. In this study, we investigated whether this two new agroecosystems could reduce nonpoint source pollution. And we found that integrated rice-duck coculture in paddy fields could reduce nonpoint source pollution. In a previous study, Quan et al. (2008) illustrated that riceduck co-culture improved the paddy water nutrient supply. Wang et al. (2004) indicated that rice-duck co-culture reduced the cardinal numbers of plant diseases and insect pests, and increased $\mathrm{N}$ and $\mathrm{P}$ uptake by rice crops. In this study, we found that the electrical conductance, oxidation-reduction potential, the contents of dissolved oxygen, nitrates, ammonium, total nitrogen, total phosphorus and total potassium in paddy water of MCDC systems were all higher than those of the mono-cropping and mixed-cropping systems, but there was no significant difference between the rice mono-cropping and mixed-cropping systems (Fig. 4 and Fig. 5).

Rice-duck co-culture system is a typical farmland ecosystem, in which rice plants or weeds are producers, ducks are top consumers, bacteria and fungi are decomposers, and other animals (e.g. spiders, locusts, rice planthoppers, etc.) are consumers as well (Fig. 7). In this ecosystem, ducks play an important role to help rice to grow by eradicating the insect pests and weeds, trampling the paddy soil, stirring the paddy water, and excreting the feces to produce the nutrients absorbed by rice plants. This highly cycling and efficient utilization of nutrients by crops in the rice-duck co-culture system with less water drainage and without chemical pesticide and herbicide additions would help to reduce nutrients(such as TN and TP) loss and runoff and other pollutants from paddy field and hence may alleviate agricultural nonpoint source pollution (Fig. 7).

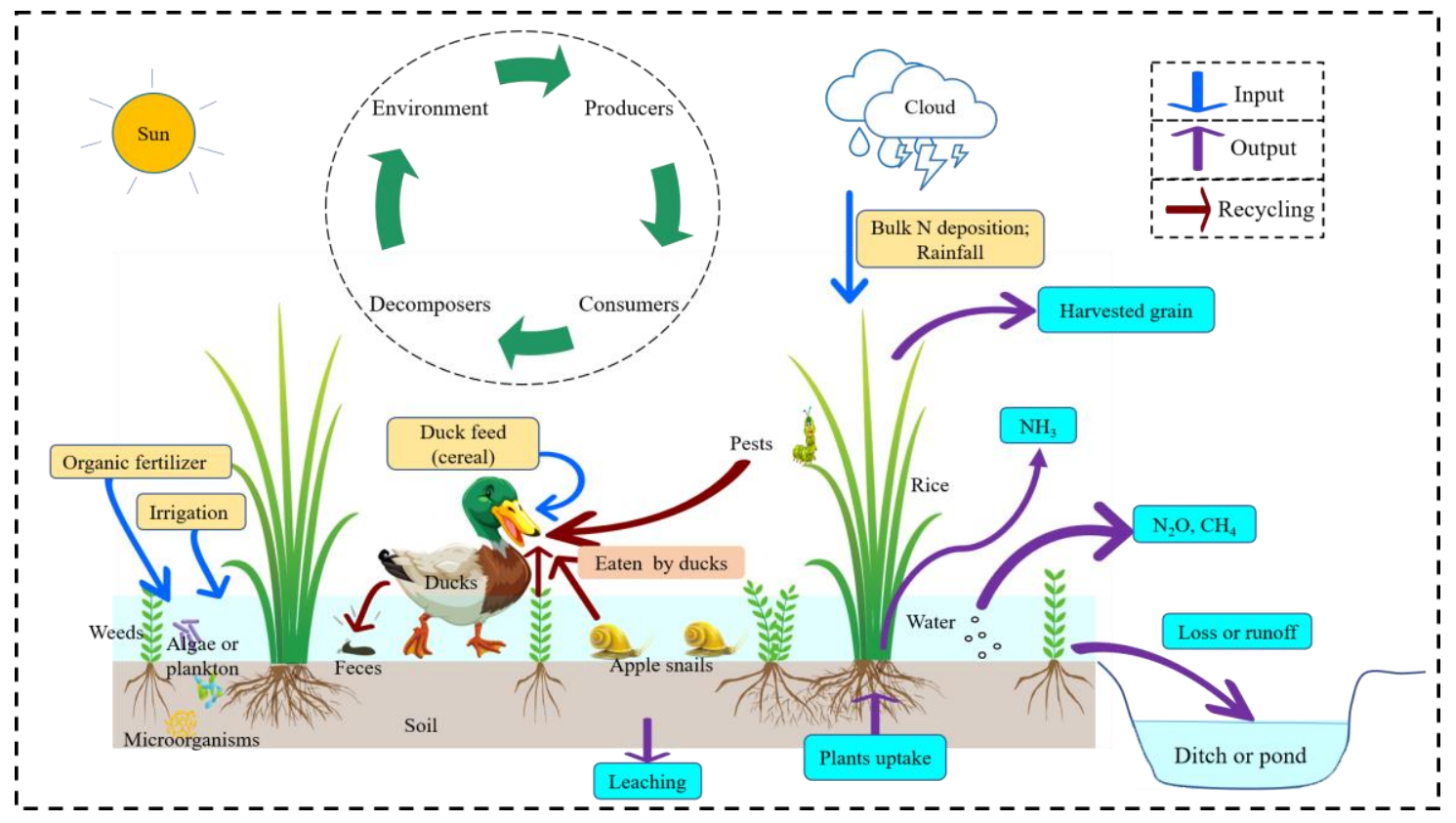

Figure 7. Outline of nutrients flows in rice-duck co-culture paddy fields. $\mathrm{NH}_{3}$, ammonia volatilization; $\mathrm{N}_{2} \mathrm{O}$, nitrous oxide; $\mathrm{CH}_{4}$, methane 
Our study is consistent with previous researches that have shown increases in the soil nutrients, paddy water nutrients, and the efficiency with which rice plants could use nutrients under oxidation reaction by increasing dissolved oxygen, strengthening oxidation-reduction potential, and improving electrical conductance. These effects resulted from ducks activities in rice paddy fields, such as touching, pecking or shaking rice plants, eating weeds, pests, apple snails and other consumable organisms, depositing fecal matter, and agitating and stirring paddy water (Zhang, 2013; Yang et al., 2018). In this study, we kept the same irrigation or drainage in each plot. But in the rice-duck co-culture system, ducks could mix paddy water in the rice fields to play a role in evenly spreading nutrients, stirring paddy water to increase dissolved oxygen and electrical conductance, and then to activate nutrients pool of paddy water and soils for rice plants to absorb availably and greatly.

Studies reported that keeping ducks in the paddy fields all day and night until rice reached the heading stage could increase the economic value of rice grains and ducks, and reduce the loss of nutrients that could potentially lead to nonpoint source pollution (Zhang et al., 2011; Zhang, 2013; Sheng et al., 2018). Moreover, some researches indicated that rice-duck co-culture system could reduce the risk of $\mathrm{N}$ and $\mathrm{P}$ runoff and leaching, and could improve the use efficiency of $\mathrm{N}$ and $\mathrm{P}$ by the growth of rice under the ducks agitating or stirring the water in paddy fields ( $\mathrm{Li}$ et al., 2008; Zhang et al., 2011; Yang et al., 2018; Teng et al., 2019). In addition, Zhang et al. (2008) found that emissions of heat-trapping gasses which contributed to global warming potential $\left(\mathrm{CH}_{4}\right.$ and $\mathrm{N}_{2} \mathrm{O}$ ) decreased when rice-duck co-culture was implemented.

Furthermore, rice-duck co-culture systems, especially those that use green or organic production techniques, could reduce or limit the use of chemical fertilizers, pesticides (Teng et al., 2016), and herbicides (Zhang et al., 2009; Teng et al., 2016), and then to decrease the nonpoint source pollution. Likewise, mixed-cropping systems are commonly used in marginal agroecological environments, where they fulfill a variety of functions, such as supplementing the use of growth factors (e.g. soil nutrients, light, and water), reducing pests and diseases incidence, reducing soil erosion, and improving total biomass production, yield stability, and household food security (Weltzien et al., 2017). Mixed-cropping systems, with different genetic diversity and species diversity from different crops or varieties, could alleviate pests and diseases and avoid the applications of chemical pesticides and herbicides. For example, Zhu et al. (2000) found that multiple cropping systems with different disease-susceptible rice cultivars could control rice disease effectively by genetic diversity of rice cultivars. Paulsen et al. (2006) also found that mixed-cropping systems could suppress weeds in linseed and reduce pests infestation in cereals or legumes. In our study, the concentrations of nitrates, ammonium, nitrogen, phosphorus, and potassium in paddy water were not significantly differed between the mixed-cropping and mono-cropping systems. However, the mixedcropping systems might reduce the pests or weeds by integrating diverse characteristics possessed by different rice cultivars (e.g. growing period, height, genotype, resistance for pests and diseases, and so on), and changing the microclimate (i.e. light, moisture, air, and temperature).

On the contrary, the conventional mono-cropping system had more applications of chemical fertilizers, pesticides and herbicides, and the nutrients were not completely absorbed by plants and then the stagnant water in rice fields could be discharged into rivers or lakes. Usually, in the rice mono-cropping systems, different kinds of chemical pesticides are overused to kill insects pests and diseases to protect crops in paddy fields, 
and they have negative impact on the environment and biodiversity (Mahmood et al., 2016; Larsen et al., 2017). Some researchers have found that only 10-20\% of the chemical pesticides applied to crops remain on the plants for a long time; $1-4 \%$ directly act on target pests, and the rest go into the atmosphere, soil, and water (Nascimento et al., 2017). Mao et al. (2002) also reported that about $9.22 \%$ of pesticides are lost into water while those were applied to rice paddy fields. Our findings reinforce that mixedcropping system which does not require synthetic chemical pesticides can reduce pollution of these chemicals.

In our study, the MCDC systems also increased electrical conductance, oxidationreduction potential, the concentrations of dissolved oxygen, nitrates, ammonium, total nitrogen, total phosphorus and total potassium of paddy water, and reduce the external inputs of synthetic chemical additives (chemical fertilizers, pesticides and herbicides). The MCDC systems showed similar/even better performances as/than the rice-duck coculture systems and the rice mixed-cropping systems. Based on the above comparative analysis, although we didn't measure and calculate the nutrient loss/runoff/leaching from the MCDC systems, we may estimate that the MCDC system could reduce total loss of $\mathrm{N}, \mathrm{P}$, and $\mathrm{K}$, and hence decrease agricultural nonpoint source pollution, because this farming approach maintains a virtuous circle within the ecosystem and without chemical pesticide and herbicide inputs, and then ensure the ecological balance of the farmland.

However, further detailed studies are needed in the future. For example, in order to know better and more accurately about the nonpoint pollution status in the MCDC and mixed cropping systems, the water quality of large-scale paddy fields and its surrounding water bodies should be monitored, and the quantity of the nutrients loss/runoff/leaching outside the paddy fields should also be measured, finally the nutrients balance analysis in paddy ecosystem should be studied as well.

\section{Conclusion}

We found that the MCDC systems increased the electrical conductance, oxidation-reduction potential, contents of dissolved oxygen, nitrates, ammonium, total nitrogen, total phosphorus, and total potassium of paddy water. The mixed-cropping systems had no differences from the mono-cropping systems in terms of their effects on physical and chemical properties of paddy water. Nevertheless, compared to the conventional rice monocropping system, both of the rice-duck co-culture and mixed-cropping systems could prevent pollution of the water environment by reducing or eliminating inputs of chemical fertilizers, herbicides and pesticides that would otherwise be applied to rice paddy fields, and lower the total loss of nutrients, pesticides and herbicides from paddy fields. Moreover, we deduced and pointed out that the MCDC systems, which exerted similar/even better performances as/than the rice-duck co-culture systems and the rice mixed-cropping systems, could reduce the application and transportation of chemical fertilizers, pesticides and herbicides into the nearby rivers or lakes, and hence could also alleviate nonpoint source pollution to a certain extent from rice production.

Acknowledgements. This study was supported by grants from the Science and Technology Project of Guangdong Province (2015B090903077, 2016A020210094, 2017A090905030), the Science and Technology Project of Guangzhou (201604020062), the Innovation Team Construction Project of Modern Agricultural Industry Technology System of Guangdong Province (2018LM1100, 2019KJ105), 
the Guangdong Provincial Key Laboratory of Eco-Circular Agriculture (2019B030301007), and the Overseas Joint Doctoral Training Program of South China Agricultural University (2018LHPY010). We would like also to thank Dr. Abe Miller-Rushing for his evaluable comments on our early manuscript, and for his assistance with English language and grammatical editing of the manuscript.

\section{REFERENCES}

[1] Asai, M., Reidsma, P., Feng, S. (2011): Impacts of agricultural land-use changes on biodiversity in Taihu Lake Basin, China: a multi-scale cause-effect approach considering multiple land-use functions. - International Journal of Biodiversity Science, Ecosystem Services \& Management 6: 119-30.

[2] Chen, Z., Wang, L., Wei, A., Gao, J., Lu, Y., Zhou, J. (2019): Land-use change from arable lands to orchards reduced soil erosion and increased nutrient loss in a small catchment. - Science of the Total Environment 648: 1097-104.

[3] Cheng, S., Zhuang, J.-Y., Fan, Y., Du, J., Cao, L. (2007): Progress in research and development on hybrid rice: a super-domesticate in China. - Annals of Botany 100: 95966.

[4] Cui, Z., Zhang, H., Chen, X., Zhang, C., Ma, W., Huang, C., Zhang, W., Mi, G., Miao, Y., Li, X. (2018): Pursuing sustainable productivity with millions of smallholder farmers. - Nature 555: 363.

[5] Dodds, W., Oakes, R. (2008): Headwater influences on downstream water quality. Environmental Management 41: 367-77.

[6] Gold, C. S. (1993): Effects of Cassava Intercropping and Varietal Mixtures on Herbivore Load, Plant Growth, and Yields: Applications for Small Farmers in Latin America. Crop-protection Strategies for Subsistence Farmers, London: Intermediate Technology Publications.

[7] Hunsaker, C. T., Levine, D. A. (1995): Hierarchical approaches to the study of water quality in rivers. - BioScience 45: 193-203.

[8] Jusi, W. (1989): Water pollution and water shortage problems in China. - Journal of Applied Ecology 26(3): 851-7.

[9] Kale, A. A. (2013): Evaluation of sieved biomass of Cicer arientinum (horse bean) for removal ofmethylene blue: batch study. - International Journal Of Recycling of Organic Waste in Agriculture 2: 18.

[10] Larsen, A. E., Gaines, S. D., Deschenes, O. (2017): Agricultural pesticide use and adverse birth outcomes in the San Joaquin Valley of California. - Nature Communication 8: 302.

[11] Li, C., Cao, C., Wang, J., Zhan, M., Yuan, W., Shahrear, A. (2008): Nitrogen losses from integrated rice-duck and rice-fish ecosystems in southern China. - Plant and Soil 307: 207-17.

[12] Li, Y., Yang, M., Zhang, Z., Li, W., Guo, C., Chen, X., Shi, X., Zhou, P., Tang, X., Zhang, Y. (2019a): An Ecological Research on Potential for Zero-growth of Chemical Fertilizer Use in Citrus Production in China. - Ekoloji 28: 1049-59.

[13] Li, M., Zhang, J., Liu, S., Ashraf, U., Zhao, B., Qiu, S. (2019b): Mixed-cropping systems of different rice cultivars have grain yield and quality advantages over mono-cropping systems. - Journal of Science of Food Agricultural 99: 3326-34.

[14] Li, M., Li, R., Liu, S., Zhang, J., Luo, H., Qiu, S. (2019c): Rice-duck co-culture farming benefits grain 2-acetyl-1-pyrroline accumulation and quality and yield enhancement of fragrant rice. - The Crop Journal 7(4): 419-30.

[15] Lithourgidis, A., Dordas, C., Damalas, C. A., Vlachostergios, D. (2011): Annual intercrops: an alternative pathway for sustainable agriculture. - Australian journal of crop science 5: 396.

[16] Liu, X., Beusen, A., Van Beek, L., Mogollon, J., Ran, X., Bouwman, A. (2018): Exploring spatiotemporal changes of the Yangtze River (Changjiang) nitrogen and 
phosphorus sources, retention and export to the East China Sea and Yellow Sea. - Water Research 142: 246-55.

[17] Luo, S. (2018): Agroecological Rice Production In China. - FAO and South China Agricultural University, $116 \mathrm{p}$.

[18] Ma, J., Chen, X., Shi, Y. (2012): Distinguishing the main pollution source an efficient way in agricultural non-point source pollution control. - Advanced Materials Research 347: 2195-9.

[19] Mahmood, I., Imadi, S. R., Shazadi, K., Gul, A., Hakeem, K. R. (2016): Effects of pesticides on environment. - In: Hakeem, K. R. (ed.) Plant, soil and microbes: 253-69. Springer.

[20] Mao, G., Wang, H., Gu, Y. (2002): Current situation of non-point source pollution of chemical fertilizer and pesticide in Shanghai and approach to controlling ways. - Acta Agriculturae Shanghai 18: 56-60.

[21] Mason, S., Leihner, D. (1988): Yield and land-use efficiency of a cassava/cowpea intercropping system grown at different phosphorus rates. - Field Crops Research 18: 215-26.

[22] Moldes, A., González, J. M. D., Rodrigues, L. R. M., Converti, A. (2013): New trends in biotechnological processes to increase the environmental protection. - BioMed research international 2013: 138018.

[23] Nascimento, M., da Rocha, G., de Andrade, J. (2017): Pesticides in fine airborne particles: from a green analysis method to atmospheric characterization and risk assessment. - Scientific Reports 7: 2267.

[24] Paulsen, H. M., Schochow, M., Ulber, B., Kuhne, S., Rahmann, G. (2006): Mixed cropping systems for control of weeds and pests in organic oilseed crops. - COR 2006, Aspects of Applied Biology 79: 215-9.

[25] Pridham, J. C., Entz, M. H., Martin, R. C., Hucl, P. J. (2007): Weed, disease and grain yield effects of cultivar mixtures in organically managed spring wheat. - Canadian journal of plant science 87: 855-9.

[26] Qin, Z., Zhang, J., Luo, S., Xu, H., Zhang, J. (2010): Estimation of ecological services value for the rice-duck farming system. - Resources Science 32: 864-72.

[27] Qiu, J. (2018): Safeguarding China's water resources. - National Science Review 5: 1027.

[28] Quan, G., Zhang, J., Chen, R., Xu, R. (2008): Effects of rice-duck farming on paddy field water environment. - Chinese Journal of Applied Ecology 19: 2023-8.

[29] Reddy, V., Cunha, D., Kurian, M. (2018): A Water-Energy-Food Nexus Perspective on the Challenge of Eutrophication. - Water 10: 101.

[30] Saraswat, C., Kumar, P., Mishra, B. K. (2016): Assessment of stormwater runoff management practices and governance under climate change and urbanization: An analysis of Bangkok, Hanoi and Tokyo. - Environmental Science \& Policy 64: 101-17.

[31] Schwarzenbach, R. P., Egli, T., Hofstetter, T. B., Von Gunten, U., Wehrli, B. (2010): Global water pollution and human health. - Annual Review of Environment and Resources 35: 109-36.

[32] Sheng, F., Cao, C., Li, C. (2018): Integrated rice-duck farming decreases global warming potential and increases net ecosystem economic budget in central China. - Environmental Science and Pollution Research 25: 22744-53.

[33] Smil, V. (1997): Global population and the nitrogen cycle. - Scientific American 277: 7681.

[34] Sun, B., Zhang, L., Yang, L., Zhang, F., Norse, D., Zhu, Z. (2012): Agricultural nonpoint source pollution in China: causes and mitigation measures. - Ambio 41: 370-9.

[35] Sun, R., Zhang, X., Guo, X., Wang, D., Chu, H. (2015): Bacterial diversity in soils subjected to long-term chemical fertilization can be more stably maintained with the addition of livestock manure than wheat straw. - Soil Biology and Biochemistry 88: 9-18. 
[36] Sun, Y., Hu, R., Zhang, C. (2019): Does the adoption of complex fertilizers contribute to fertilizer overuse? Evidence from rice production in China. - Journal of Cleaner Production 219: 677-85.

[37] Teng, Q., Hu, X., Cheng, C., Luo, Z., Luo, F., Xue, Y., Jiang, Y., Mu, Z., Liu, L., Yang, M. (2016): Ecological effects of rice-duck integrated farming on soil fertility and weed and pest control. - Journal of Soils and Sediments 16: 2395-407.

[38] Teng, Q., Hu, X., Luo, F., Wang, J., Zhang, D. (2019): Promotion of rice-duck integrated farming in the water source areas of Shanghai: its positive effects on reducing agricultural diffuse pollution. - Environmental Earth Sciences 78: 171

[39] Thomas, C. S., Nelson, N. P., Jahn, G. C., Niu, T., Hartley, D. M. (2011): Use of media and public-domain Internet sources for detection and assessment of plant health threats. Emerging Health Threats Journal 4: 7157.

[40] Vandermeer, J., van Noordwijk, M., Anderson, J., Ong, C., Perfecto, I. (1998): Global change and multi-species agroecosystems: concepts and issues. - Agriculture, Ecosystems \& Environment 67: 1-22.

[41] Wang, Q., Huang, P., Zhen, R., Jing, L., Tang, H., Zhang, C. (2004): Effect of rice-duck mutualism on nutrition ecology of paddy field and rice quality. - The journal of applied ecology 15: 639-45.

[42] Wang, P., Zhang, W., Li, M., Han, Y. (2019): Does Fertilizer Education Program Increase the Technical Efficiency of Chemical Fertilizer Use? Evidence from Wheat Production in China. - Sustainability 11: 543.

[43] Weltzien, E., Christinck, A. (2017): Participatory breeding: developing improved and relevant crop varieties with farmers. - Agricultural Systems, Agroecology and rural innovation for development: 259-301.

[44] Wu, Y. (2011): Chemical fertilizer use efficiency and its determinants in China's farming sector. - China Agricultural Economic Review 3: 117-30.

[45] Wu, M., Tang, X., Li, Q., Yang, W., Jin, F., Tang, M., Scholz, M. (2013): Review of Ecological Engineering Solutions for Rural Non-Point Source Water Pollution Control in Hubei Province, China. - Water, Air, \& Soil Pollution 224: 1561.

[46] Xiang, H., Zhang, J., Luo, M., Zhao, B., Quan, G. (2013): Effects of intercropping rice with Oenanthe javanica on diseases, pests and weeds hazards and yield of rice. - Journal of Ecology and Rural Environment 29: 58-63.

[47] Yang, H., Yu, D., Zhou, J., Zhai, S., Bian, X., Weih, M. (2018): Rice-duck co-culture for reducing negative impacts of biogas slurry application in rice production systems. Journal of Environmental Management 213: 142-50.

[48] Yin, H., Zhao, W., Li, T., Cheng, X., Liu, Q. (2018): Balancing straw returning and chemical fertilizers in China: Role of straw nutrient resources. - Renewable and Sustainable Energy Reviews 81: 2695-702.

[49] Yin, G., Lin, Z., Jiang, X., Yan, H., Wang, X. (2019): Spatiotemporal differentiations of arable land use intensity - A comparative study of two typical grain producing regions in northern and southern China. - Journal of Cleaner Production 208: 1159-70.

[50] Zhang, J., Lu, J., Huang, Z., Zhang, G. (2005): Discussion on practical and theoretic issues of integrated rice-duck farming system. - Ecologic Science 24: 49-51.

[51] Zhang, J., Ouyang, Y., Huang, Z. (2008): Characterization of nitrous oxide emission from a rice-duck farming system in South China. - Archives of Environmental Contamination and Toxicology 54: 167-72.

[52] Zhang, J., Shan, Q., Qian, H., Xu, Y.-h., Cao, M.-j. (2008): Effects and planting techniques of hedgerow intercropping on sloping lands in agricultural non-point source pollution control. - Bulletin of Soil and Water Conservation 5: 180-5.

[53] Zhang, J., Xu, R., Chen, X., Quan, G. (2009): Effects of duck activities on a weed community under a transplanted rice-duck farming system in southern China. - Weed Biology and Management 9: 250-7. 
[54] Zhang, J., Zhang, F., Yang, J., Wang, J., Cai, M., Li, C., Cao, C. (2011): Emissions of $\mathrm{N} 2 \mathrm{O}$ and $\mathrm{NH} 3$, and nitrogen leaching from direct seeded rice under different tillage practices in central China. - Agriculture, ecosystems \& environment 140: 164-73.

[55] Zhang, J. (2013): Progresses and perspective on research and practice of rice-duck farming in China. - Chinese Journal of Eco-Agriculture 21: 70-9.

[56] Zhu, Y., Chen, H., Fan, J., Wang, Y., Li, Y., Chen, J., Fan, J., Yang, S., Hu, L., Leung, H. (2000): Genetic diversity and disease control in rice. - Nature 406: 718.

\section{APPENDIX}

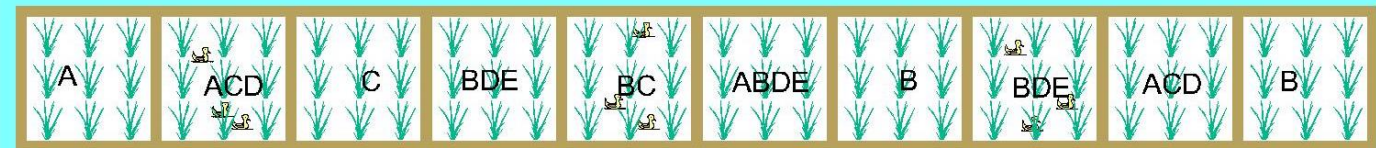

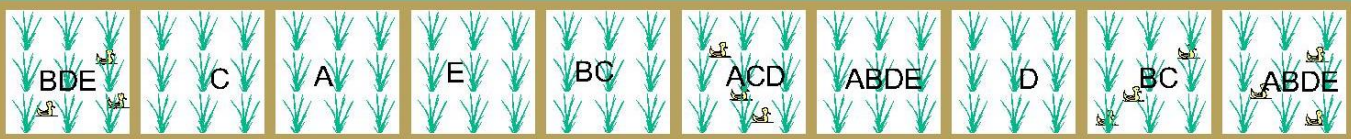

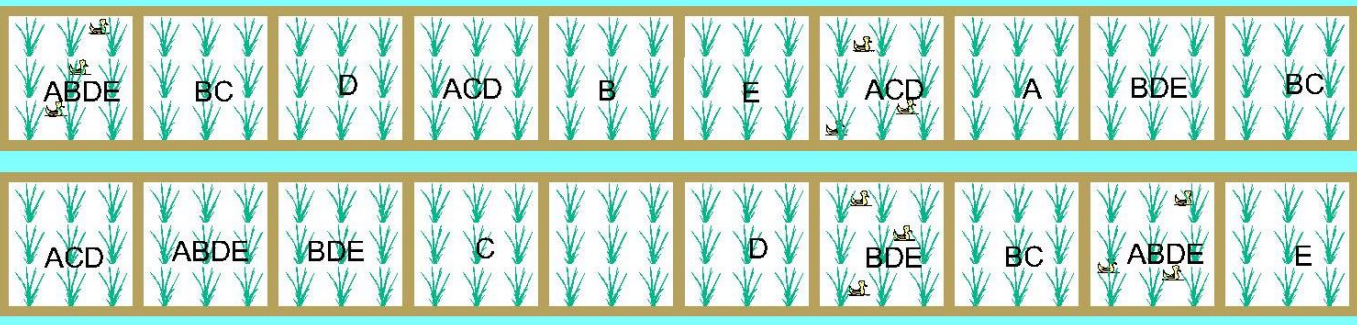

Figure S1. Design of mono-cropping, mixed-cropping, and MCDC treatments in the paddy field. The A, B, C, D, and E stand for Yuenongsimiao, Meixiangzhan 2, Huangguangyouzhan, Huanghuazhan and Huahang31, respectively. Two or more letters indicate the treatments of mixed-cropping systems or MCDC systems (with duck in the plots). For example, BC stands for the treatment of mixed-cropping system with the rice cultivars of Meixiangzhan 2 and Huangguangyouzhan or stands for the treatments of rice-duck co-culture with different rice cultivars (MCDC) of Meixiangzhan 2 and Huangguangyouzhan. Other treatments are labelled similarly. In the figure, one plot was one replication of one treatment

Table S1. Traits of the five rice varieties that accessed from the China Rice Data Center

\begin{tabular}{|c|c|c|c|c|c|c|c|c|c|c|c|}
\hline $\begin{array}{l}\text { Rice } \\
\text { cultivars }\end{array}$ & $\begin{array}{l}\text { Period } \\
\text { (d) }\end{array}$ & $\begin{array}{l}\text { Height } \\
(\mathrm{cm})\end{array}$ & \begin{tabular}{|c} 
Spikelet per \\
panicle \\
$\left(10^{4} \mathrm{ha}^{-1}\right)$ \\
\end{tabular} & $\begin{array}{c}\text { Seed setting } \\
\text { rate } \\
(\%)\end{array}$ & $\begin{array}{c}\text { 1000-grain } \\
\text { weight } \\
(\mathrm{g})\end{array}$ & $\begin{array}{c}\text { Head rice } \\
\text { rate } \\
(\%)\end{array}$ & \begin{tabular}{|c|}
$\begin{array}{c}\text { Chalky rice } \\
\text { rate } \\
(\%)\end{array}$ \\
\end{tabular} & \begin{tabular}{|c|}
$\begin{array}{c}\text { Chalkiness } \\
\text { degree } \\
(\%)\end{array}$ \\
\end{tabular} & \begin{tabular}{|c|}
$\begin{array}{c}\text { Amylose } \\
\text { content } \\
(\%)\end{array}$ \\
\end{tabular} & $\begin{array}{c}\text { Length/ } \\
\text { width }\end{array}$ & $\begin{array}{l}\text { Yield } \\
\left(\mathrm{t} \mathrm{ha}^{-1}\right)\end{array}$ \\
\hline Yuenongsimiao (A) & $111 \sim 113$ & $97.0 \sim 97.9$ & $122 \sim 124$ & $87.1 \sim 88.0$ & $22.0 \sim 22.6$ & $71.8 \sim 73.0$ & $3 \sim 6$ & $0.5 \sim 0.9$ & $17.3 \sim 18.2$ & $3.3 \sim 3.5$ & 6.57 \\
\hline Meixiangzhan 2 (B) & $112 \sim 113$ & $90.5 \sim 96.6$ & 145.1 & $83.9 \sim 87.7$ & $18.1 \sim 18.5$ & $63.7 \sim 67$ & $8 \sim 20$ & $0.8 \sim 1.4$ & $15 \sim 17.6$ & - & 5.31 \\
\hline $\begin{array}{l}\text { Huangguangyouzhan } \\
\text { (C) }\end{array}$ & $128 \sim 132$ & $107.7 \sim 110.1$ & $133 \sim 144$ & $84.9 \sim 87.2$ & $24.5 \sim 24.6$ & 44.0 & $8 \sim 11$ & $1.0 \sim 2.5$ & $13.7 \sim 15.9$ & 3.1 & 7.62 \\
\hline Huanghuazhan (D) & $129 \sim 131$ & $93.8 \sim 102.8$ & $118.3 \sim 123$ & $80.5 \sim 86.8$ & $22.2 \sim 23.1$ & $40.0 \sim 55.2$ & $4 \sim 6$ & $0.6 \sim 3.2$ & $13.8 \sim 14.0$ & - & 7.20 \\
\hline Huahang 31 (E) & $110 \sim 111$ & $109.5 \sim 110.6$ & $132.1 \sim 132$ & $83.5 \sim 85.8$ & $22 \sim 22.3$ & $70.4 \sim 72.5$ & $4 \sim 18$ & $0.8 \sim 6.9$ & $16.2 \sim 16.5$ & - & 6.31 \\
\hline
\end{tabular}

Data from: http://www.ricedata.cn/ 


$$
-1297 \text { - }
$$

Table S2. ANOVA analysis for the water physical and chemical properties of the treatments before ducklings were released in the paddy fields

\begin{tabular}{|c|c|c|c|c|c|c|}
\hline Indexes & Treatments & Df & Sum Sq & Mean Sq & F value & $\operatorname{Pr}(>\mathbf{F})$ \\
\hline \multirow{8}{*}{$\mathrm{pH}$} & $\mathrm{BC}$ & 2 & 0.1225 & 0.06125 & 2.670 & 0.123 \\
\hline & & 9 & 0.2064 & 0.02294 & & \\
\hline & $\mathrm{ACD}$ & 2 & 0.1818 & 0.0909 & 2.451 & 0.128 \\
\hline & & 12 & 0.445 & 0.03708 & & \\
\hline & $\mathrm{BDE}$ & 2 & 0.0275 & 0.01374 & 0.347 & 0.714 \\
\hline & & 12 & 0.4751 & 0.03959 & & \\
\hline & ABDE & 2 & 0.1435 & 0.07173 & 1.401 & 0.277 \\
\hline & & 15 & 0.7682 & 0.05121 & & \\
\hline \multirow{8}{*}{ Temp } & $\mathrm{BC}$ & 2 & 1.352 & 0.6758 & 1.284 & 0.323 \\
\hline & & 9 & 4.737 & 0.5264 & & \\
\hline & $\mathrm{ACD}$ & 2 & 2.45 & 1.226 & 0.292 & 0.752 \\
\hline & & 12 & 50.45 & 4.204 & & \\
\hline & $\mathrm{BDE}$ & 2 & 0.98 & 0.488 & 0.134 & 0.876 \\
\hline & & 12 & 43.62 & 3.635 & & \\
\hline & $\mathrm{ABDE}$ & 2 & 3.95 & 1.977 & 0.548 & 0.589 \\
\hline & & 15 & 54.1 & 3.607 & & \\
\hline \multirow{8}{*}{$\mathrm{EC}$} & $\mathrm{BC}$ & 2 & 0.262 & 0.1308 & 0.045 & 0.957 \\
\hline & & 9 & 26.375 & 2.9306 & & \\
\hline & $\mathrm{ACD}$ & 2 & 5.91 & 2.954 & 0.648 & 0.540 \\
\hline & & 12 & 54.69 & 4.558 & & \\
\hline & $\mathrm{BDE}$ & 2 & 1.767 & 0.8833 & 0.343 & 0.716 \\
\hline & & 12 & 30.87 & 2.5725 & & \\
\hline & ABDE & 2 & 5.86 & 2.929 & 0.766 & 0.482 \\
\hline & & 15 & 57.38 & 3.825 & & \\
\hline \multirow{8}{*}{ ORP } & $\mathrm{BC}$ & 2 & 760.7 & 380.4 & 2.623 & 0.127 \\
\hline & & 9 & 1305.4 & 145 & & \\
\hline & $\mathrm{ACD}$ & 2 & 73.9 & 36.97 & 0.557 & 0.587 \\
\hline & & 12 & 796.1 & 66.34 & & \\
\hline & $\mathrm{BDE}$ & 2 & 291.2 & 145.6 & 0.656 & 0.537 \\
\hline & & 12 & 2664.1 & 222 & & \\
\hline & ABDE & 2 & 373.4 & 186.7 & 0.960 & 0.405 \\
\hline & & 15 & 2916.1 & 194.4 & & \\
\hline \multirow{8}{*}{ DO } & $\mathrm{BC}$ & 2 & 0.272 & 0.1361 & 0.215 & 0.811 \\
\hline & & 9 & 5.704 & 0.6337 & & \\
\hline & $\mathrm{ACD}$ & 2 & 1.8 & 0.9002 & 2.080 & 0.168 \\
\hline & & 12 & 5.193 & 0.4327 & & \\
\hline & $\mathrm{BDE}$ & 2 & 1.66 & 0.8302 & 1.427 & 0.278 \\
\hline & & 12 & 6.98 & 0.5817 & & \\
\hline & $\mathrm{ABDE}$ & 2 & 1.93 & 0.9648 & 1.950 & 0.177 \\
\hline & & 15 & 7.423 & 0.4948 & & \\
\hline
\end{tabular}




$$
-1298-
$$

Table S3. ANOVA analysis for the water nutrient concentration of the treatments before ducklings were released in the paddy fields

\begin{tabular}{|c|c|c|c|c|c|c|}
\hline Indexes & Treatments & Df & Sum Sq & Mean Sq & F value & $\operatorname{Pr}(>F)$ \\
\hline \multirow{8}{*}{$\mathrm{NO}_{3}^{-}$} & $\mathrm{BC}$ & 2 & 0.0000419 & 0.00002097 & 0.428 & 0.664 \\
\hline & & 9 & 0.0004409 & 0.00004898 & & \\
\hline & $\mathrm{ACD}$ & 2 & 0.00005356 & 0.00002678 & 1.160 & 0.346 \\
\hline & & 12 & 0.0002769 & 0.00002308 & & \\
\hline & BDE & 2 & 0.0000269 & 0.00001346 & 0.281 & 0.760 \\
\hline & & 12 & 0.0005742 & 0.00004785 & & \\
\hline & $\mathrm{ABDE}$ & 2 & 0.0001017 & 0.00005083 & 0.738 & 0.495 \\
\hline & & 15 & 0.0010329 & 0.00006886 & & \\
\hline \multirow{8}{*}{$\mathrm{NH}_{4}^{+}$} & $\mathrm{BC}$ & 2 & 0.01626 & 0.008132 & 0.371 & 0.700 \\
\hline & & 9 & 0.1971 & 0.0219 & & \\
\hline & $\mathrm{ACD}$ & 2 & 0.07208 & 0.03604 & 1.467 & 0.269 \\
\hline & & 12 & 0.29491 & 0.02458 & & \\
\hline & $\mathrm{BDE}$ & 2 & 0.05649 & 0.02824 & 2.431 & 0.130 \\
\hline & & 12 & 0.13942 & 0.01162 & & \\
\hline & $\mathrm{ABDE}$ & 2 & 0.00178 & 0.000889 & 0.091 & 0.914 \\
\hline & & 15 & 0.14665 & 0.009776 & & \\
\hline \multirow{8}{*}{$\mathrm{TN}$} & $\mathrm{BC}$ & 2 & 0.5209 & 0.2604 & 0.757 & 0.497 \\
\hline & & 9 & 3.0947 & 0.3439 & & \\
\hline & $\mathrm{ACD}$ & 2 & 0.173 & 0.08661 & 0.282 & 0.759 \\
\hline & & 12 & 3.68 & 0.30667 & & \\
\hline & $\mathrm{BDE}$ & 2 & 0.535 & 0.2675 & 0.412 & 0.672 \\
\hline & & 12 & 7.797 & 0.6497 & & \\
\hline & $\mathrm{ABDE}$ & 2 & 0.281 & 0.1403 & 0.247 & 0.785 \\
\hline & & 15 & 8.531 & 0.5687 & & \\
\hline \multirow{8}{*}{$\mathrm{TP}$} & $\mathrm{BC}$ & 2 & 0.02526 & 0.01263 & 1.403 & 0.295 \\
\hline & & 9 & 0.08105 & 0.009005 & & \\
\hline & $\mathrm{ACD}$ & 2 & 0.01489 & 0.007445 & 1.278 & 0.314 \\
\hline & & 12 & 0.06988 & 0.005823 & & \\
\hline & BDE & 2 & 0.00193 & 0.000966 & 0.253 & 0.781 \\
\hline & & 12 & 0.04585 & 0.00382 & & \\
\hline & $\mathrm{ABDE}$ & 2 & 0.00011 & 0.0000534 & 0.021 & 0.979 \\
\hline & & 15 & 0.03831 & 0.0025542 & & \\
\hline \multirow{8}{*}{ TK } & $\mathrm{BC}$ & 2 & 0.079 & 0.0393 & 0.033 & 0.968 \\
\hline & & 9 & 10.748 & 1.1943 & & \\
\hline & $\mathrm{ACD}$ & 2 & 0.526 & 0.263 & 0.237 & 0.792 \\
\hline & & 12 & 13.299 & 1.108 & & \\
\hline & $\mathrm{BDE}$ & 2 & 1.716 & 0.8581 & 1.356 & 0.294 \\
\hline & & 12 & 7.593 & 0.6328 & & \\
\hline & ABDE & 2 & 1.464 & 0.7322 & 0.715 & 0.505 \\
\hline & & 15 & 15.354 & 1.0236 & & \\
\hline
\end{tabular}




$$
-1299 \text { - }
$$

Table S4. ANOVA analysis for the water physical and chemical properties of the treatments after ducklings were released in the paddy fields

\begin{tabular}{|c|c|c|c|c|c|c|}
\hline Indexes & Time & Df & Sum Sq & Mean Sq & F value & $\operatorname{Pr}(>\mathrm{F})$ \\
\hline \multirow{6}{*}{$\mathrm{Ph}$} & \multirow{2}{*}{ 27th May } & 2 & 0.0049 & 0.00245 & \multirow[t]{2}{*}{0.054} & \multirow[t]{2}{*}{0.948} \\
\hline & & 36 & 1.6424 & 0.04562 & & \\
\hline & \multirow{2}{*}{ 22nd June } & 2 & 0.6204 & 0.31019 & \multirow[t]{2}{*}{6.708} & \multirow[t]{2}{*}{0.00334} \\
\hline & & 36 & 1.6647 & 0.04624 & & \\
\hline & \multirow{2}{*}{ 18th July } & 2 & 2.684 & 1.3419 & \multirow[t]{2}{*}{5.559} & \multirow[t]{2}{*}{0.00787} \\
\hline & & 36 & 8.69 & 0.2414 & & \\
\hline \multirow{6}{*}{ Temp } & \multirow{2}{*}{ 27th May } & 2 & 0.433 & 0.2167 & \multirow[t]{2}{*}{1.194} & \multirow[t]{2}{*}{0.315} \\
\hline & & 36 & 6.536 & 0.1815 & & \\
\hline & \multirow{2}{*}{ 22nd June } & 2 & 9.774 & 4.887 & \multirow[t]{2}{*}{90.79} & \multirow[t]{2}{*}{$8.64 \mathrm{E}-15$} \\
\hline & & 36 & 1.938 & 0.054 & & \\
\hline & \multirow{2}{*}{ 18th July } & 2 & 19.29 & 9.646 & \multirow[t]{2}{*}{6.283} & \multirow[t]{2}{*}{0.00456} \\
\hline & & 36 & 55.27 & 1.535 & & \\
\hline \multirow{6}{*}{$\mathrm{EC}$} & \multirow{2}{*}{ 27th May } & 2 & 56.02 & 28.009 & \multirow[t]{2}{*}{17.54} & \multirow[t]{2}{*}{$4.81 \mathrm{E}-06$} \\
\hline & & 36 & 57.49 & 1.597 & & \\
\hline & \multirow{2}{*}{ 22nd June } & 2 & 1334.9 & 667.4 & \multirow[t]{2}{*}{38.32} & \multirow[t]{2}{*}{$1.21 \mathrm{E}-09$} \\
\hline & & 36 & 627.1 & 17.4 & & \\
\hline & \multirow{2}{*}{ 18th July } & 2 & 454.2 & 227.09 & \multirow[t]{2}{*}{28.22} & \multirow[t]{2}{*}{$4.25 \mathrm{E}-08$} \\
\hline & & 36 & 289.7 & 8.05 & & \\
\hline & 27th May & 2 & 7364 & 3682 & 18.5 & $2.97 \mathrm{E}-06$ \\
\hline & 2/th May & 36 & 7163 & 199 & & \\
\hline OPP & & 2 & 5625 & 2812.4 & 16.4 & 8.63E-06 \\
\hline ORP & 22nd June & 36 & 6172 & 171.5 & & \\
\hline & 18th Julv & 2 & 1118 & 559.2 & 3.918 & 0.0289 \\
\hline & 18th July & 36 & 5139 & 142.7 & & \\
\hline & 27th Moy & 2 & 8.989 & 4.495 & 5.22 & 0.0102 \\
\hline & z/tu viay & 36 & 31 & 0.861 & & \\
\hline ח & 22 nd Jun & 2 & 42.22 & 21.112 & 20.17 & $1.33 \mathrm{E}-06$ \\
\hline DU & L2nd June & 36 & 37.69 & 1.047 & & \\
\hline & 18th July & 2 & 2.981 & 1.4903 & 2.821 & 0.0727 \\
\hline & 18th July & 36 & 19.016 & 0.5282 & & \\
\hline
\end{tabular}




$$
-1300-
$$

Table S5. ANOVA analysis for the water nutrient concentration of the treatments after ducklings were released in the paddy fields

\begin{tabular}{|c|c|c|c|c|c|c|}
\hline Indexes & Time & Df & Sum Sq & Mean Sq & $F$ value & $\operatorname{Pr}(>\mathbf{F})$ \\
\hline \multirow{6}{*}{$\mathrm{NO}_{3}^{-}$} & \multirow{2}{*}{ 27th May } & 2 & 0.2392 & 0.1196 & \multirow[t]{2}{*}{4.004} & \multirow[t]{2}{*}{0.0269} \\
\hline & & 36 & 1.0755 & 0.02987 & & \\
\hline & \multirow{2}{*}{ 22nd June } & 2 & 0.3218 & 0.1609 & \multirow[t]{2}{*}{323.8} & \multirow[t]{2}{*}{$<2 \mathrm{e}-16$} \\
\hline & & 36 & 0.0179 & 0.0005 & & \\
\hline & \multirow{2}{*}{ 18th July } & 2 & 0.14638 & 0.07319 & \multirow[t]{2}{*}{97.7} & \multirow[t]{2}{*}{$2.85 \mathrm{E}-15$} \\
\hline & & 36 & 0.02697 & 0.00075 & & \\
\hline \multirow{6}{*}{$\mathrm{NH}_{4}{ }^{+}$} & \multirow{2}{*}{ 27th May } & 2 & 6.272 & 3.1362 & \multirow[t]{2}{*}{146.4} & \multirow[t]{2}{*}{$<2 \mathrm{e}-16$} \\
\hline & & 36 & 0.771 & 0.0214 & & \\
\hline & \multirow{2}{*}{ 22nd June } & 2 & 25.658 & 12.829 & \multirow[t]{2}{*}{473.4} & \multirow[t]{2}{*}{$<2 \mathrm{e}-16$} \\
\hline & & 36 & 0.976 & 0.027 & & \\
\hline & \multirow{2}{*}{ 18th July } & 2 & 1.1982 & 0.5991 & \multirow[t]{2}{*}{42.06} & \multirow{2}{*}{$3.81 \mathrm{E}-10$} \\
\hline & & 36 & 0.5128 & 0.0142 & & \\
\hline \multirow{6}{*}{$\mathrm{TN}$} & \multirow{2}{*}{ 27th May } & 2 & 317.8 & 158.89 & \multirow[t]{2}{*}{126.6} & \multirow[t]{2}{*}{$<2 \mathrm{e}-16$} \\
\hline & & 36 & 45.2 & 1.26 & & \\
\hline & \multirow{2}{*}{ 22nd June } & 2 & 669.9 & 334.9 & \multirow{2}{*}{543} & \multirow{2}{*}{$<2 \mathrm{e}-16$} \\
\hline & & 36 & 22.2 & 0.6 & & \\
\hline & \multirow{2}{*}{ 18th July } & 2 & 23.39 & 11.694 & \multirow[t]{2}{*}{18.84} & \multirow[t]{2}{*}{$2.52 \mathrm{E}-06$} \\
\hline & & 36 & 22.35 & 0.621 & & \\
\hline & & 2 & 80.43 & 40.22 & 158 & $<2 \mathrm{e}-16$ \\
\hline & 27th May & 36 & 9.16 & 0.25 & & \\
\hline TP & & 2 & 214.22 & 107.1 & 133.7 & $<2 \mathrm{e}-16$ \\
\hline $1 \mathrm{P}$ & & 36 & 28.84 & 0.8 & & \\
\hline & & 2 & 1.1367 & 0.5684 & 29.88 & $2.25 \mathrm{E}-08$ \\
\hline & 18th July & 36 & 0.6848 & 0.019 & & \\
\hline & & 2 & 1516.9 & 758.5 & 153.3 & $<2 \mathrm{e}-16$ \\
\hline & 2/th May & 36 & 178.1 & 4.9 & & \\
\hline TK & 22nd June & 2 & 6775 & 3387 & 75.73 & $1.26 \mathrm{E}-13$ \\
\hline in & z2nd Jume & 36 & 1610 & 45 & & \\
\hline & & 2 & 12.06 & 6.028 & 14.36 & $2.60 \mathrm{E}-05$ \\
\hline & 18th July & 36 & 15.12 & 0.42 & & \\
\hline
\end{tabular}

